\title{
Halal Meat Fraud and Safety Issues in the UK: a Review in the Context of the European Union
}

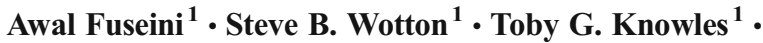 \\ Phil J. Hadley ${ }^{2}$
}

Accepted: 15 January 2017 / Published online: 26 January 2017

(C) Springer International Publishing Switzerland 2017

\begin{abstract}
Since the discovery of horsemeat in some processed beef products in early 2013, there has been increased speciation testing of products of meat origin within the EU. This led to the detection of porcine DNA and subsequently pork meat in some processed "Halal" products in the UK. This situation caused a great deal of panic and distress among the UK Muslim population, as the consumption of pork or its derivatives is strictly forbidden in Islam. This paper considers what makes meat Halal and discusses existing gaps in Halal certification and the regulation of Halal meat that potentially expose the Halal market to fraudulent activity.
\end{abstract}

Keywords Halal meat $\cdot$ Food safety $\cdot$ Meat fraud $\cdot$ Stunning $\cdot$ Slaughter

\section{Introduction}

The adulteration and mislabelling of meat and other food products is not a new phenomenon. Within the EU, there are stringent measures in place to protect and promote foods that are traditional specialties and have geographical indications such as Protected Geographical Indication (PGI), Protected Designation of Origin (PDO) and Traditional Specialties Guaranteed (TSG) and law protects these. Relevant EU food safety and labelling legislation also seeks to prevent the adulteration and production of foods that may pose a public health risk, as well as the misrepresentation (through mislabelling) of food in order to deceive consumers. Despite these preventative measures, certain individuals, in using unapproved methods, succeed to produce food that is unfit for human consumption or not correctly described. These individuals are more often than not, motivated by greed, and a desire to maximise profits. Halal meat is that derived from animals slaughtered in

Awal Fuseini

awalfus@yahoo.com

1 School of Veterinary Science, University of Bristol, Langford, Bristol BS40 5DU, UK

2 AHDB, Creech Castle, Bathpool, Taunton TA1 2DX, UK 
accordance with the Islamic dietary laws enshrined in the Quran (Islamic Holy Book) and the Hadith (The traditions of the Prophet of Islam, Mohammed). The majority of practicing Muslims will only consume Halal meat, as many regard the consumption of such meats as a form of worship. Due to the spiritual significance of Halal meat to Muslims consumers, in addition to the economic benefits associated with trading in such meats due to the expansion in the global Muslim population, there has been competition for a share of the Halal market by mainstream food business operators in the industrialised world. The Pew Research Centre (2015) projected that if the current trends continue, the global Muslim population will increase by $73 \%$ to 2.8 billion by the year 2050. Despite the apparent economic benefits associated with trading in Halal food products, many Halal consumers have expressed concern about the lack of understanding of the rules surrounding the slaughter of animals, and the subsequent processing or handling of these products for Muslim consumption. The situation is exacerbated by the fact that many Halal Food Business Operators in the West are non-Muslims with limited or no understanding of the Islamic dietary laws. Also, the recent discovery of fraudulent activities in the Halal industry (BBC 2014, 2015; Huffington Post 2014a; Mail Online 2015) has aggravated the situation. The detection of undeclared horsemeat (and horse DNA) in some products in the UK (Food Standards Agency, FSA 2013; The Guardian 2013a) led to more stringent tests of processed foods for undeclared materials (FSA 2014), which has resulted in prosecutions (FSA 2015; Food Safety News 2015). The subsequent increase in product testing led to the detection of pork meat and porcine DNA in various "Halal" products destined for Muslim consumption (The Guardian 2013b; ITV News 2013). Muslims are forbidden to farm, trade or consume pork or any by-product from pigs.

Whilst many fraudulent activities in the Halal industry, such as the intentional mislabelling of non-Halal meat as Halal, or the contamination of Halal meat with pork (and its derivatives) or other non-Halal materials, may be motivated by the desire of some unscrupulous Food Business Operators (FBOs) to maximise profits, the inability of Halal Certification Bodies (HCBs) to agree on a unified Halal standard may be considered to be partially to blame for some of the lapses in the understanding of the requirements of the Islamic dietary laws. Some HCBs, for instance, approve food-processing sites, which, in addition to processing Halal products, may also process pork or other non-Halal materials using the same equipment and processing lines. Although these sites claim to 'thoroughly' clean the equipment after the processing of pork, other $\mathrm{HCBs}$ are of the view that the cleaning may still expose Halal products to porcine DNA contamination and will not certify such a site. In the UK, porcine DNA has been detected in 'Halal' savoury beef pastry products originating from a processing plant where pork and the "Halal" products in question were processed using the same equipment (The Guardian 2013b). Notwithstanding the disagreement on the processing of Halal and pork or pork derivatives on the same processing lines by HCBs, there appears to be differences in Halal standards regarding the acceptability of pre-slaughter stunning of animals, machine (mechanical) slaughter of birds, thoracic (chest) sticking of ruminants and some aspects intensive livestock production systems.

This paper attempts to define Halal meat, whilst highlighting gaps and loopholes within Halal certification and enforcement that expose Halal meat to fraud. It also considers the differences that exist between the Halal standards used by different Halal authorities across the EU. The paper contributes to the literature regarding the definition of Halal in terms of animal welfare and food safety. 


\section{What is Halal}

Halal is an Arabic word that literally means anything that is permissible or lawful (Riaz 1996; Fuseini et al. 2016a). When used in relation to meat, such meats must be derived from specific animals slaughtered in accordance with requirements specified in the Quran and Hadith. Extensive reviews of the requirements of Halal slaughter have recently been conducted (Farouk 2013; Fuseini et al. 2016a, b). It is generally agreed within the Muslim community that for meat to be acceptable for consumption by Muslims, the animal must be a species that is accepted for Halal, more importantly, it must also be fit and well at the time of slaughter and that sufficient time must be allowed for the loss of blood, which leads to irreversible loss of brain function. The Quran expressly forbids Muslims from consuming blood. This may be due to the role residual blood (in the carcass) plays in the spoilage (and palatability) of meat, particularly against the background that at the time the Quran was revealed, there were no advanced technologies such as refrigeration systems for the preservation of meat. Kirton et al. (1981) suggested that poor bleeding-out at exsanguination results in poor keeping and eating quality. There is lack of evidence to support the hypothesis that the method of stunning or slaughter affects the loss of blood as quoted below. It must be emphasised, however, that blood loss at exsanguination cannot be literally complete, as residual blood will always remain in the capillaries whether animals are slaughtered with or without stunning. Hence the religious ban on the consumption of blood must be interpreted as an intention for proper bleeding, i.e. removing as much blood as it is practically possible from the carcass.

Despite the fact that Islamic authorities around the world unanimously agree on some of the requirements of Halal slaughter, there are other aspects of Halal slaughter that have divided opinion among Islamic jurists, leading to confusion among Halal consumers, food business operators and other stakeholders in the Halal industry as to what is authentic Halal meat. For instance, European Council regulation, EC 1099/2009 requires the preslaughter stunning of all animals before slaughter in order to induce immediate loss of consciousness, however, paragraph 18 EC1099/2009 gives derogation for slaughter without stunning, it is enshrined within this legislation as well as in some member states for faith groups. Some Islamic jurists have vehemently argued against the use of any form of stunning for Halal slaughter, whilst others are of the opinion that pre-slaughter stunning is Halal compliant, on condition that the stunning itself is fully recoverable and does not lead to injury (to the animal). Opponents of pre-slaughter stunning for Halal slaughter have often cited the possibility of animals dying following stunning and before exsanguination as the main reason pre-slaughter stunning contradicts the Islamic dietary rules. Others are of the opinion that the stunning of animals prior to slaughter results in the retention of more blood in the carcass in comparison with those slaughtered without stunning. However, repeated research has demonstrated that there is no difference in animals that are slaughtered either with or without pre-slaughter stunning in terms of the total blood lost at exsanguination (Khalid et al. 2015; Anil et al. 2006; Gomes Neves et al. 2009). In addition, some methods of stunning e.g. head-only electrical stunning support the full recovery of animals if they are not slaughtered post-stunning (Wotton et al. 2014; Orford et al. 2016). These misconceptions produce disagreements within the Muslim community, which, in addition to the lack of an overarching regulatory authority for Halal food in EU member states, and other countries in the developed world, opens the door for misinterpretation and potential fraudulent activities in the Halal food industry. 


\section{The Market for Halal Meat}

The demand for Halal meat is on the rise and it is projected to continue to grow (Farouk 2013; Sungkar 2008; Bonne and Verbeke 2008). Many factors contribute to the exponential growth in demand for Halal meat. Lever and Miele (2012) cited the UK and France as the two EU countries where for over a decade there has been uninterrupted growth in the demand for meats slaughtered according to the Halal rules. The global expansion in Muslim population (Pew Research Centre 2015) may be responsible for the continued growth of the Halal meat market. However, some researchers have suggested that the growth of the Halal meat market within the EU is attributed to the increased migration of Muslims across Europe in recent years (Bergeaud-Blackler 2004). Although this observation was made over a decade ago, the recent exodus of Muslim refugees from countries such as Syria, Iraq, Afghanistan and Libya into the $\mathrm{EU}$, due to the surge in religious extremism and on-going wars in those countries, has reaffirmed migration as one of the most important factors influencing the growth of the EU Halal meat market. Also, the continued increase in the export of Halal certified meat and processed meat products from the EU to Muslim-majority countries such as Turkey, Indonesia, Malaysia, the UAE and Singapore is another important factor influencing the growth of the Halal meat market in Europe. Temporal (2011) reported that the Asia Pacific region accounts for the largest share of the global Halal export, whilst Singapore was identified as the single most important centre for the transit of Halal products en-route to the major importing countries. It must be noted that the consumption of Halal meat is not restricted to Muslim consumers. In the UK and other parts of Europe, many non-Muslims continue to patronise Halal restaurants and fast food chains that clearly advertise their meat as Halal with little or no information as to whether animals were pre-stunned or not. Notable among these restaurants and fast food chains include Kentucky Fried Chicken (KFC), Subway, Nandos, and a large number of Indian restaurants on the high street. Some of these establishments are solely "Halal restaurants" and all products in such restaurants are usually certified Halal by one of the numerous HCBs that exist. It is therefore not surprising that the mainstream retail multiples within the EU, including Albert Heijn, Aldi, Asda, ,Carrefour, Marks and Spencer, Morrisons, Sainsbury's, Tesco and Waitrose have all started stocking fresh or processed Halal meat products (Awan et al. 2015; The Telegraph 2014). These retailers are always quick to emphasise that they do not sell unstunned meat under their own label, however, unstunned meat may still be sold in some of the stores, usually under a third party label. Despite the scramble for a share of the Halal meat market by the major retail multiples, the preferred point of purchase of Halal meat by the majority of Muslims is the local Halal butcher (Riaz 1996; Becker et al. 1998; Glitsch 2000; Ahmed 2008; Bonne and Verbeke 2008). This may have influenced the recent opening of Muslim-butcher stalls in many of the supermarkets within the UK. In a survey involving 300 UK Halal consumers, the majority of respondents $(90 \%)$ indicated that they were unaware of the fact that some of the major supermarket chains sold Halal meat. The findings also revealed that the majority of Halal consumers (96\%) prefer to shop at the local Muslim-butcher shop because they trusted their compliance with Halal more than the supermarket chains (Ahmed 2008). Although some non-Muslims continue to consume Halal meat willingly (or unknowingly), others avoid it for the reason that they consider such meats can be from animals slaughtered in an inhumane manner, albeit a significant proportion of Halal meat is stunned prior to slaughter. In fact, within the EU, the proportion of Halal meat stunned before slaughter has been reported as $65 \%$ of cattle, $50 \%$ of small ruminants and $50 \%$ of poultry (DIALREL 2010). In the case of slaughter by followers of 
the Jewish faith (Shechita), all forms of stunning have been rejected, leading to the slaughter of all animals without stunning. It does appear however, that, a significant proportion of the animals slaughtered according to the rules of Shechita cannot be consumed by the Jewish community due to the presence of the "forbidden fat" (tallow) and the sciatic nerve in the hindquarters. These "unfit products" are therefore passed onto the non-Kosher market (Conway and Lichtenstein 2015; RSPCA 2015), because within the EU, there is currently no legal requirement for meat to be labelled with the slaughter method or, more specifically, whether the meat originates from animals stunned pre-slaughter, post-cut stunned or unstunned. Whilst some animal welfare proponents are calling for meat to be labelled as either stunned or unstunned (if the legislation continues to permit non-stun slaughter) to provide clarity to consumers (RSPCA 2015), organisations representing the veterinary profession have called for a total ban on the slaughter of animals without stunning within the EU on animal welfare grounds (BVA 2015; FVE 2016).

\section{Halal Meat Certification in Europe}

The ultimate goal of the certification of meat as Halal by third-party HCBs is to provide assurance to Halal consumers that some key requirements have been met during the slaughter, processing, packaging, storage or transport of the meat. This is particularly important within the EU and other industrialised countries where many FBOs may be unfamiliar with the requirements of Halal, additionally, there is increased risk of cross contamination of Halal food with non-Halal products such as pork during further processing, storage or transport. The concept of Halal certification within the EU is a relatively new phenomenon. In the UK, the first HCB ever to certify meat as Halal, the Halal Food Authority (HFA), was established in 1994. According to this organisation, their main objective at inception was to "monitor and authenticate" the Halal status of poultry and red meat because the Halal status of up to $85 \%$ of "Halal meat" in the UK at the time could not be verified (HFA 2016). Opponents of Halal food certification have often questioned the motives of those ventures. It has been suggested that the exponential increase in the population of Muslims across Europe in recent years may have contributed to the increase in the number of unregulated HCBs, all with the aim of independently verifying Halal status, and facilitating the trade in Halal products (Fuseini et al. 2016b). Within the UK alone, there are over $10 \mathrm{HCBs}$ who are all competing applying varying Halal standards in their quest to assure consumers about the authenticity of Halal meat certified by themselves. There have been accusations and counter-accusations among the certifiers as to whose Halal standard is genuine. The lack of government involvement or a central monitoring body of HCBs has meant that any individual can set-up an HCB with little or no technical expertise about meat, potentially a lack of specific religious knowledge and/or non-mainstream agreement about what makes meat Halal. Lack of technical understanding has led to a lack of proper monitoring and scrutiny of some Halal certificated sites, which has resulted in the contamination of Halal products at processing sites where Halal and non-Halal products are produced in tandem but with poor segregation and/or cleaning (Talib and Johan 2012). Others have been accused of approving slaughter technologies that violate the basic requirements of Halal slaughter. Although many Muslims would appear to prefer meat from animals slaughtered without stunning because the method guarantees a live, uninjured animal at the time of slaughter (EBLEX 2010), 
recent covert filming at non-stun Halal slaughterhouses by animal welfare activists in Belgium and the UK have highlighted systemic abuse and suffering of animals destined for the Halal food chain (PETA 2009; Newsweek 2015). These practices would have undoubtedly violated the animal welfare requirements of Halal slaughter enshrined in the Quran and Hadith. It must be emphasised that such violations are also common in Muslimmajority countries where very painful and violent methods are used in coercing and restraining animals prior to slaughter. These include the hoisting of conscious animals (usually ruminants) by the hind leg prior to slaughter, slashing of tendons in the hind legs in order to immobilise conscious animals prior to slaughter and the lifting of small ruminants by their wool or limbs (CIWF 2007, 2008, 2012). There is therefore a need for proper monitoring and regulation of Halal slaughter in Muslim-majority countries too, the mere fact that an animal is not stunned prior to slaughter does not necessarily make the meat compliant with all the Halal slaughter requirements. Some of the problems that exist within Halal certification could be rectified with a unified global Halal standard. This would ensure that all HCBs operate under the same rules, and would be analogous to the current EU 'Organic' standard overseen by a number of certification bodies all operating to the same overarching rules. The Organisation of Islamic Cooperation (OIC), an intergovernmental organisation with 57 member states is currently working on the development of a global Halal Standard (OIC 2015). Pointing et al. (2008) pointed out that until there is clarity or consensus on the correct definition of Halal, enforcement agencies would find it difficult to protect Halal consumers. Further, consumer law, according to Pointing et al. (2008), does not currently give sufficient protection to Halal consumers despite the Muslim authorities having made attempts to develop quality standards to instil some confidence in Halal products.

The high cost of Halal certification to FBOs is another area that has attracted attention. The annual certification fee for an abattoir or food-processing site in the UK in 2016 can range from a few hundreds of pounds to tens of thousands of pounds, depending upon the HCB. The certification fee may be insignificant to the major players in the meat industry, however, to small throughput plants and food businesses, this potential cost can be significant. In an attempt to avoid a fee, some FBOs have been found to intentionally mislabel non-Halal meat as Halal, others have resorted to "self-certification", this is where an FBO verifies its own Halal status and communicates this to the Halal consumer. This practice is common among Muslim owned food businesses. Whilst some businesses have successfully implemented this model, others have struggled to effectively put it into operation. The practice of "selfcertification" can only be used where the target consumers are local, this is because most Halal importing countries require a Halal certificate to accompany all Halal meat products before such products can be given clearance. Lever and Miele (2012) cited a French Halal lamb distributor, Halaldom, as a company that has successfully utilised "self-certification" of its Halal products. According to the authors, this has been possible due to a "strong communication strategy with Muslim consumers" and their commitment to the community displayed by donating a percentage of the income received for every order back to the community.

Despite the shortfalls of HCBs highlighted above, many Halal consumers regard them as the enforcers of the Islamic dietary laws in the developed world. They are also regarded by many FBOs as facilitators for Halal trade. This is because certificates issued by some of these organisations have become respected and are accepted by local Halal consumers and importers of Halal meat to Muslim-majority countries. It is worth noting that despite the existence of a large number of HCBs across the $28 \mathrm{EU}$ member states, only a handful of these organisations 
can issue certificates for export to the international Halal market. This is because certificates issued by the local HCB can only be accepted in the importing destination if authorities in those countries accredit them. Table 1 is a list of some of the major HCBs within the EU and the countries where their certificates are accepted.

\section{Halal Meat Safety}

The procedure for the slaughter of animals for consumption by Muslims is not markedly different from conventional slaughter, with the exception of where animals are slaughtered without any form of pre-slaughter stunning. Halal slaughter with pre-slaughter stunning involves the same procedure as conventional slaughter, however, the former requires the recitation of a short prayer before or during slaughter to satisfy the religious requirements. One may therefore assume that the safety of meat should not be affected by the two methods described above, albeit post-slaughter processing or handling may affect food safety. At the time the Quran and other Islamic scriptures were revealed some 1400 years ago, there were no food safety regulations, however, the concept of Tayyib (wholesome/safe foods) was incorporated into Halal to cater for food safety, albeit this aspect is seldom given the attention it deserves within the Muslim community. It has been suggested that the concept of Halal food safety according to the standards of the major HCBs is ambiguous (Demirci et al. 2016). This may be due to the fact that many HCBs have concentrated on the issue of slaughter whilst ignoring other important aspects such as the Tayyib requirements. Sirajuddin et al. (2013) noted that the failure of Muslim authorities to incorporate Tayyib into Halal meat production has exposed gaps in the safety of Halal meat, they have suggested a more holistic approach in interpreting the scriptures regarding the "Halal-Tayyib" concept of food production. Nonetheless, Cutler (2007) pointed out that Halal and Kosher (religiously slaughtered meat for Jews) meats are prepared under much stricter standards in comparison with meat from conventionally slaughtered animals (for consumers with no religious requirements governing meat production). This improves both the quality and safety of Halal and Kosher foods (Asghar

Table 1 Major HCBs within the EU and the countries in which their certificates are recognised

\begin{tabular}{lllll}
\hline Halal Certification Body (HCB) & \multicolumn{3}{l}{ Accreditation of HCB in Halal-importing country } \\
\cline { 2 - 5 } & Malaysia & Indonesia & Singapore UAE \\
& (JAKIM) & (MUI) & (MUIS) \\
\hline Halal Control, Germany & Yes & Yes & Yes & No \\
Halal Feed and Food Inspection Authority, The Netherlands & Yes & Yes & Unknown & Yes \\
Halal Food Authority, UK & Yes & Yes & Yes & Yes \\
Halal Food Council of Europe, Belgium & Yes & Yes & Yes & Yes \\
Halal Institute of Spain, Spain & No & Yes & Yes & No \\
Halal International Authority, Italy & Yes & Yes & Yes & Yes \\
Halal Monitoring Committee, UK & No & No & No & Yes \\
Halal Quality Control, The Netherlands & Yes & Yes & Yes & Yes \\
Islamic Information and Documentation Centre, Austria & Yes & No & Yes & Yes \\
Ritual Association of Lyon Great Mosque, France & Yes & No & Yes & Yes \\
The Grand Mosque of Paris-SFCVH, France & No & Yes & Unknown Unknown \\
The Muslim Religious Union in Poland, Poland & Yes & Yes & Unknown Unknown \\
Total Quality Halal Correct, The Netherlands & Yes & Yes & Yes & Yes \\
\hline
\end{tabular}


et al. 1990; Farouk et al. 2014). On the contrary, the hygiene of the premises of most Muslim local butchers has often raised serious meat safety concerns, some of these premises often lack basic hygiene facilities such as facilities for hand washing or designated changing areas. It is not uncommon to see a local Muslim butcher handling or cutting meat with no hairnet, coat or apron. Huffington Post (2014b) reported that although Halal meat may guarantee spiritual purity, it does not necessarily guarantee safe meat. The report cited a number of incidents where Halal meat was found to be unfit for human consumption (Food Safety News 2009, 2013). One of the biggest seizures of unsafe Halal meat by food safety officers was recently reported in Glasgow (The Evening Times 2016). Approximately 1 tonne of unsafe meat, believed to be lamb was supplied to two Halal butchers operating in the Glasgow area. The Evening Times (2016) reported that these butchers were suppliers to some of the city's many food outlets.

The majority of the issues surrounding Halal meat safety include illegal slaughter of livestock, poor labelling and documentation, and poor hygiene and sanitation of Halal meat premises and personnel. These incidents of food fraud and food safety are not by any means restricted to the Halal meat industry. In Belgium and Ireland, the introduction of dioxin into the human food chain through the use of contaminated fat in animal feed (Casey et al. 2010) is still fresh in the minds of many Belgian and Irish consumers. Tahkapaa et al. (2015) suggested that these incidents might have prompted the adoption of EU Regulation 178/2002 in the EU. This regulation lays down the general principles pertaining to feed and food safety within the EU and at national levels.

\section{Halal Meat Fraud}

Some researchers have described food fraud as an ancient practice usually driven by profit (Manning et al. 2016). The fraudulent trading in meat that is claimed to be Halal can take many forms, from the sale of illegally slaughtered animals generally associated with poor animal welfare, to the sale of unwholesome meat for human consumption, which poses a risk to human health. Manning and Soon (2014) argued that the fraudulent trading in foods that pose a public health risk are more often detected at a stage where the food is already at a point of sale or has potentially been consumed. In a recent food crime annual strategic assessment report in the UK, the Food Standards Agency (FSA) in conjunction with Food Standards Scotland (FSS) defined food crime as "dishonesty on the part of the producer or supplier" (FSA/FSS 2016). Table 2 shows different forms of food crime and the threat each may pose (FSA/FSS 2016), food crime within the Halal industry may fall under one of these categories. Food businesses (including Halal producers) are expected to be familiar with these offences, and steps must be taken to prevent them. In the UK, organised criminal gangs are usually involved in these activities, a situation which because of the potential scale, raises food safety concerns among regulatory and food safety professionals (Pointing and Teinaz 2004). These authors explained that the most common offences included the sale of reprocessed chicken sludge bleached to improve its aesthetic value, the importation of unfit bush meat and "smokies" from parts of West Africa where such products are considered as delicacies. Blow-torching the skin or hide of an animal before splitting the carcass produces a "smokie", and is thought to improve the taste of the meat. Although banned within the EU (EC Regulation EC1662/2006), these products continue to be illegally imported into Europe for human consumption in some member states (Chaber et al. 2010; BBC 2010). Aside the dangers these products pose to 


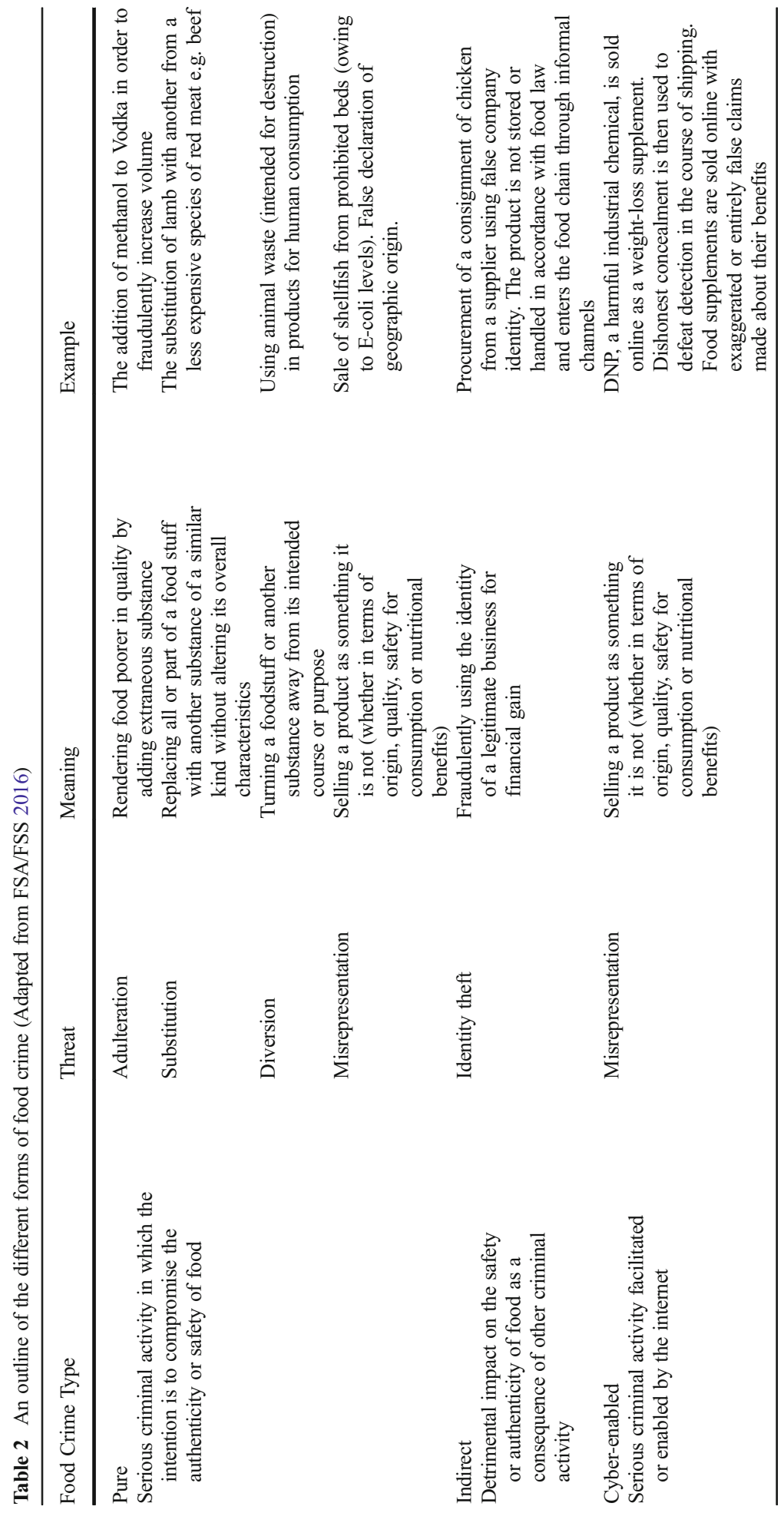


public health, there are concerns for animal welfare and also conservation of endangered species. It has been reported that carcasses of endangered species such as giraffes, gorillas and chimpanzees have all been imported from Africa and sold within the EU as bush meat (Pointing and Teinaz 2004). Some products may end up in the Halal food chain with no proper documentation of their Halal status.

\section{Illegal Slaughter}

Illegal slaughter is the slaughter of animals for human consumption outside a licensed establishment (EC853/2004), except where permission is granted for the slaughter to be performed outside a licensed premise, such as the on-farm slaughter of animals for personnel use only - on-farm slaughtered meat cannot be sold to the general public, it must be used by the owner (usually the farmer) or his/her immediate family. In addition to meeting the EU legislative requirements specified in EC1099/2009, animals destined for the Halal food chain must also be slaughtered in the Islamic tradition. Any meat that falls short of the two requirements above is deemed unfit for Muslim consumption. Guidance issued to Local Enforcement Authorities in the UK (FSA 2009) highlights the following scenarios that should arouse suspicion regarding the legality of meat:

- The slaughter of animals at unlicensed establishments

- The cutting of meat at unlicensed premises

- Unlabelled or poorly health-marked meat

- Meat that may have been imported through illegal channels

- Meat that is advertised, marketed and sold by itinerant vendors at car boot sales, pubs, clubs and other public gatherings

- Meat that was slaughtered legally but may become unfit to consume within the interpretation of EC178/2002 due to storage under unsanitary conditions or at temperatures outside the legal limits.

Table 3 below lists examples of fraudulent activities discovered in the Halal meat industry in the UK. Muslims are instructed, according to the Islamic scriptures (Quran and Hadith) to consume only Halal meat, many Muslims therefore regard the consumption of Halal meat as a religious act, hence the significance of consuming Halal meat to a Muslim cannot be underestimated. It is therefore surprising, that some Muslims or food businesses owned by Muslims have been implicated directly or indirectly in the majority of the crimes committed regarding the falsification of the status of Halal meat. This, according to experts in the Halal certification or regulation industry is why some production is motivated by greed and a desire to maximise profits by means either by fair or foul.

\section{Mislabelling of Halal Meat}

The accurate labelling, presentation and advertisement of foodstuffs within the EU must comply with Article 2 of Council Directive 2000/13/EC. This specifically makes it an offence for the labelling of any food product to mislead consumers regarding the characteristics, identity, constituents, quantity, method of manufacture, durability and geographical origin of the product. Despite the lack of clarity regarding the true meaning or definition of Halal, the intentional mislabelling of non-Halal products as Halal in order to mislead consumers into 
Table 3 A list of some of the reported crimes involving Halal meat in the UK

\begin{tabular}{|c|c|c|}
\hline Incident & Fine imposed & Source \\
\hline $\begin{array}{l}\text { A Halal Meat Company in Bradford used } \\
\text { counterfeit Halal labels on meat products } \\
\text { and sold them as Halal }\end{array}$ & $£ 20,000$ & $\begin{array}{l}\text { http://birminghamnewsroom. } \\
\text { com/meat-supplier-ordered-to- } \\
\text { pay-nearly-20000-for-fake-halal-labels/ }\end{array}$ \\
\hline $\begin{array}{l}\text { A Halal meat wholesaler in Birmingham } \\
\text { mislabelled and sold non-Halal meat } \\
\text { as Halal. }\end{array}$ & $£ 62,000$ & $\begin{array}{l}\text { http://www.halaltimes. } \\
\text { com/fake-birmingham-halal-meat- } \\
\text { company-fined-62000-pounds/ }\end{array}$ \\
\hline $\begin{array}{l}\text { A Halal Meat supplier in Birmingham } \\
\text { misled Halal consumers by claiming } \\
\text { their products were certified by the } \\
\text { Halal Monitoring Committee }\end{array}$ & $£ 1100$ & $\begin{array}{l}\text { http://birminghamnewsroom. } \\
\text { com/halal-meat-supplier-fined- } \\
\text { for-misleading-customers/ }\end{array}$ \\
\hline $\begin{array}{l}\text { Halal Meat butcher in Manchester } \\
\text { mixed cheap minced beef with minced } \\
\text { lamb and sold it as } 100 \% \text { lamb }\end{array}$ & $£ 18,000$ & $\begin{array}{l}\text { http://www.manchestereveningnews.co. } \\
\text { uk/news/greater-manchester-news/halal- } \\
\text { butchers-food-fraud-trafford-11178552 }\end{array}$ \\
\hline $\begin{array}{l}\text { A meat processor in Newry, Northern } \\
\text { Ireland, falsely labelled non-Halal } \\
\text { burgers as Halal }\end{array}$ & $£ 70,000$ & $\begin{array}{l}\text { http://www.bbc.co.uk/news/uk-northern- } \\
\text { ireland-33317601 }\end{array}$ \\
\hline $\begin{array}{l}\text { A meat supplier in Walton Summit, } \\
\text { supplied Halal "chicken" kebabs to } \\
\text { one of the major retailers which } \\
\text { were found to contain mainly } \\
\text { connective tissues and beef. }\end{array}$ & $£ 10,000$ & $\begin{array}{l}\text { http://www.lep.co.uk/news/business/ } \\
\text { food-firm-hit-by-kebab-fine-1-4670081 }\end{array}$ \\
\hline $\begin{array}{l}\text { Four men illegally slaughtered sheep } \\
\text { for the Eid festivities at unlicensed } \\
\text { premises without prior stunning }\end{array}$ & $£ 2075$ & $\begin{array}{l}\text { http://www.express.co. } \\
\text { uk/news/uk/580745/Islam-Muslim-halal- } \\
\text { slaughter-farm-UK-Llechrydau-Farm-court }\end{array}$ \\
\hline
\end{tabular}

purchasing such products constitutes an offence. The doubts surrounding the true meaning of Halal meat is brought about by the sketchy interpretation of the Islamic scriptures by Muslim scholars with regard to modern livestock farming and animal slaughter practice. This lack of agreement between HCBs makes it difficult for Local Enforcement Officers to identify fraudulent activities in the Halal meat trade. On one hand, some Muslims are reluctant to accept any farming, animal slaughter or meat processing technique that was not used by the Prophet of Islam, on the other hand, there are Muslims who have recognised the need to accept technologies that do not explicitly violate the Islamic slaughter guidelines, as they were not available at the time of the Prophet. Halal meat may be mislabelled in two ways; false declaration of meat species and the presence of undeclared meat species (Chuah et al. 2016). A series of surveys regarding the labelling of chicken products in the UK concluded that there was widespread mislabelling of chicken (FSA 2001, 2003). With regard to chicken labelled as Halal, the following worrying conclusions were reached:

- There was widespread mislabelling of Halal chicken.

- The addition of water to 'pump up' chicken was a common practice. In some instances, over $50 \%$ of the chicken weight was added water..

- The water used in "pumping-up" the chicken was found to contain proteins to aid the retention of water in the carcasses, these proteins were of porcine and bovine origin. As mentioned above, it is forbidden for Muslims to consume pork or its derivatives, in addition, the bovine protein may have been derived from animals slaughtered contrary to the Islamic slaughter requirements.

- Additives used in chicken were often not included on labels. 
Aldi Supermarket had to apologise to its UK Muslim consumers after a product containing pig blood and pig skin was mislabelled as Halal by its producer (International Business Times 2015). The retailer indicated that it was an isolated incident and that it did not pose any food safety risks to consumers. The adulteration and mislabelling of Halal meat is not restricted to the EU, Chuah et al. (2016) tested 143 processed "Halal" meat (beef and poultry) products in Malaysia for the presence of Halal-prohibited proteins from pigs, rats, cats, donkeys, dogs and other undeclared Halal-acceptable species. They found that $78 \%$ of the products were mislabelled. In addition, buffalo DNA was detected in 40 out of 58 products labelled as beef whilst 33 out of the 58 products contained undeclared chicken. However, none of the Halalprohibited products were found in those tested.

\section{Contamination of Halal Meat}

Meat derived from pigs, carnivorous animals, birds of prey and animals slaughtered contrary to Islamic principles are regarded as non-Halal. The cross-contamination of Halal meat with any of these products will negate the Halal status of the meat. Pork appears to be the most important product of concern for the majority of Muslims living in the West, this is because most Halal meat producing facilities in these countries also handle and process pork alongside Halal meat products. This practice increases the risk of cross-contamination between the Halal products and pork, particularly where there are poor segregation and cleaning between the two products. The detection of even very low levels of pork or porcine genetic materials in Halal products will render the products non-Halal. Due to this concern, a number of researchers have attempted to use different testing techniques to determine the identity of meat protein in Halal products in order to reassure Halal consumers of the authenticity of Halal products (Murugaiah et al. 2009; Demirhan et al. 2012; Stamoulis et al. 2010; Ulca et al. 2013). The Malaysia government recently signed a Memorandum of Understanding (MoU) with a UK based testing facility, Fera Science, for the provision of Halal proficiency testing (Global Meat News 2016). The aim of the agreement is for Fera Science to develop protocols for the detection of pork and alcohol in low levels in Halal products. These protocols are therefore restricted to species and alcohol detection and not the wider ethical issues in the Halal industry.

\section{Conclusion}

The consumption of Halal meat is an important aspect of the dictums of the Islamic faith. However, the desire of some Halal meat suppliers to maximise profits has led to a series of incidents involving the mislabelling of products that do not meet the Halal dietary laws as Halal. Incidents of this nature can cause significant distress to practicing Muslims. Divergent views within the Muslim community regarding what is authentic Halal have resulted in confusion among FBOs, Halal consumers and stakeholders in the industry. This also makes it difficult for law enforcement agencies to identify and prosecute offenders of Halal meat fraud. Nonetheless, in recent years, there have been a number of successful prosecutions of Halal meat suppliers who intentionally sold non-Halal meat as Halal. The health and safety aspects of Halal meat has also been questioned, as a significant proportion originates from smaller, potentially less well managed and regulated processors. Some researchers have suggested that the adoption of a holistic "Halal-Tayyib" concept of livestock agriculture and meat production would alleviate some of the food safety risks associated with post-slaughter 
handling of Halal meat. Further research is needed to understand the Islamic scholarly interpretation of the Halal-Tayyib concept and how this can be incorporated into modern livestock agriculture and food processing systems. The successful implementation of this concept would improve animal welfare during Halal slaughter as well as eliminate the food safety risks associated with Halal food production. Halal Certification Bodies need to engage to play this vital role in ensuring the successful implementation of this concept.

Acknowledgements AF acknowledges the support of the Humane Slaughter Association (HSA) through an Animal Welfare Research Training (PhD) Scholarship and also the support of AHDB Beef and Lamb

\section{References}

Ahmed, A. 2008. Marketing of halal meat in the United Kingdom. British Food Journal 110: 655670 .

Anil, M.H., T. Yesildere, H. Aksu, E. Matur, J.L. Mckinstry, H.R. Weaver, O. Erdogan, S. Hughes, and C. Mason. 2006. Comparison of Halal slaughter with captive bolt stunning and neck cutting in cattle: Exsanguination and quality parameters. Animal Welfare 15: 325-330.

Asghar, A., E. Torres, J.I. Gray, and A.M. Pearson. 1990. The effect of salt on myoglobin derivatives in the sarcoplasmic extract from pre-and post-rigor beef in the presence or absence of mitochondria and microcosms. Meat Science 27: 197-209.

Awan, H.M., A.N. Siddiquei, and Z. Haider. 2015. Factors affecting Halal purchase intention- evidence from Pakistan's Halal food sector. Management Research Review 38: 640-660.

BBC. 2010. Illegal bushmeat 'rife in Europe'. http://www.bbc.co.uk/news/10341174. Accessed 21 June 2016.

BBC. 2014. Birmingham Butcher to pay $£ 62,000$ for false halal sale. http://www.bbc.co.uk/news/uk-englandbirmingham-29157457. Accessed 7 June 2016.

BBC. 2015. Food company Freeza Meats fined $£ 70,000$ costs. http://www.bbc.co.uk/news/uk-northern-ireland33317601. Accessed 7 June 2016.

Becker, T., E. Benner, and K. Glitsch. 1998. Summary Report on Consumer Behaviour towards Meat in Germany, Ireland, Italy, Spain, Sweden and the United Kingdom - Results of a Consumer Survey, Report submitted to the Commission of the European Union, Selbstverlag, Gottingen.

Bergeaud-Blackler, F. 2004. Le chevillard et le sacrificateur: la viande halal entre logiques économiques, légales et religieuses. In L'islam en France, eds. S. Taussig, C. Fleury, 537-545. Paris: Presses Universitaires de France.

Bonne, K., and W. Verbeke. 2008. Muslim consumer trust in halal meat status and control in Belgium. Meat Science 79: 113-123.

British Veterinary Association (BVA). 2015. BVA calls on government to end non-stun slaughter on day of parliamentary debate. https://www.bva.co.uk/News-campaigns-and-policy/Newsroom/News-releases/BVAcalls-on-Government-to-end-non-stun-slaughter-on-day-of-Parliamentary-debate/. Accessed 13 June 2016.

Casey, D.K., J.S. Lawless, and P.G. Wall. 2010. A tale of two crisis: The Belgian and Irish dioxin contamination incidents. British Food Journal 112: 1077-1091.

Chaber, A., S. Allebone-Webb, Y. Lignereux, A.A. Cunningham, and J.M. Rowcliffe. 2010. The scale of illegal meat importation from Africa to Europe via Paris. Conservation Letters 3: 317-323.

Chuah, L., X. Bin He, M.E. Effarizah, Z.A. Syahariza, A.K. Shamila-Syuhada, and G. Rusul. 2016. Mislabelling of beef and poultry products sold in Malaysia. Food Control 62: 157-164.

Compassion in World Farming (CIWF). 2007. Middle East: Further OIE welfare guideline breaches. http://www. ciwf.org.uk/news/2007/11/middle-east-cruelty-further-evidence-of-serious-breaches-of-oie-welfareguidelines. Accessed 27 Nov 2016.

Compassion in World Farming (CIWF). 2008. New video reveals animal welfare guidelines ignored. http://www. ciwf.org.uk/news/2008/10/new-film-reveals-animal-welfare-international-guidelines-are-ignored. Accessed 27 Nov 2016.

Compassion in World Farming (CIWF). 2012. OIE failing animals. http://www.ciwf.org.uk/news/2012/05/oiefailing-animals. Accessed 27 Nov 2016.

Conway, R.J., and D.Y.Y. Lichtenstein. 2015. Can we eat from the hindquarters? http://www.shechita. org/faqs/extra-q-can-we-eat-from-the-hindquarters/. Accessed 13 June 2016. 
Council Regulation (EC) No 1099/2009. Council Regulation on the protection of animals at the time of killing. http:/eur-lex.europa.eu/LexUriServ/LexUriServ.do?uri=OJ:L:2009:303:0001:0030:EN:PDF. Accessed 27 Nov 2016.

Cutler, T.R. 2007. Food safety drives growth in Kosher \& Halal foods. http://www.halalrc. org/images/Research\%20Material/Literature/Food\%20Safety\%20Drives\%20Growth\%20in\%20Kosher\%20 $\% 26 \% 20$ Halal\%20Foods.pdf. Accessed 21 June 2016.

Demirci, M.N., J.M. Soon, and C.A. Wallace. 2016. Positioning food safety in Halal assurance. Food Control 70: 257-270.

Demirhan, Y., P. Ulca, and H.Z. Senyuva. 2012. Detection of porcine DNA in gelatine and gelatine-containing processed food products-Halal/Kosher authentication. Meat Science 90: 686-689.

DIALREL. 2010. Report on good and adverse practices- Animal welfare concerns in relation to slaughter practices from the viewpoint of veterinary sciences. http:/www.dialrel.eu/images/veterinary-concerns.pdf. Accessed 20 May 2016.

EBLEX. 2010. Report on the Halal meat market: Specialist supply chain structures and consumer purchase and consumption profiles in England by the English Beef \& Lamb Executive. www.qsmbeefandlamb.co. uk/halal. Accessed 23 June 2016.

European Council Regulation (EC178/2002). Laying down the general principles and requirements of food law, establishing the European Food Safety Authority and laying down procedures in matters of food safety. http:/eur-lex.europa.eu/LexUriServ/LexUriServ.do?uri=OJ:L:2002:031:0001:0024:en:PDF. Accessed 22 June 2016.

European Council Regulation. (EC853/2004). Laying down specific hygiene rules for on the hygiene of foodstuffs. http://eur-lex.europa.eu/LexUriServ/LexUriServ.do?uri=OJ:L:2004:139:0055:0205:en:PDF. Accessed 22 June 2016.

European Council Regulation. (EC1662/2006). Council Regulation (EC) No 1662/2006 of 6 November 2006 amending Regulation (EC) No 853/2004 of the European Parliament and of the Council laying down specific hygiene rules for food of animal origin. http://eur-lex.europa.eu/LexUriServ/LexUriServ.do?uri= OJ:L:2006:320:0001:0010:EN:PDF. Accessed 22 June 2016.

Farouk, M.M. 2013. Advances in the industrial production of halal and kosher red meat. Meat Science 95: 805820 .

Farouk, M.M., H.M. Al-Mazeedi, A.B. Sabow, A.E.D. Bekhit, K.D. Adeyemi, A.Q. Sazili, and A. Ghani. 2014. Halal and kosher slaughter methods and meat quality: A review. Meat Science 98: $505-519$.

Food Safety News. 2009. Texas sues Halal group over food safety. http://www.foodsafetynews.com/2009/12 /texas-sues-halal-group-over-filthy-conditions/\#.V2iQrVeXg5S. Accessed 21 June 2016.

Food Safety News. 2013. BC Halal producer charged with selling unfit meat. http://www.foodsafetynews. com/2013/01/bcs-halal-producer-charged-with-selling-unfit-meat/\#.V2iSYleXg5S. Accessed 20 June 2016.

Food Safety News. 2015. Defendants sentenced in UK horsemeat scandal: judge notes suspicion of complicity. http://www.foodsafetynews.com/2015/03/defendants-sentenced-in-uk-horse-meat-scandal/. Accessed 7 June 2016.

Food Standards Agency UK (FSA). 2001. Water added to restaurant and take-away chicken, survey finds. http://tna.europarchive.org/20110116113217/http://www.food.gov.uk/news/newsarchive/2001 /dec/chickwater?view=printerfriendly. Accessed 27 June 2001.

Food Standards Agency UK (FSA). 2003. FSA water in chicken update. http://tna.europarchive. org $/ 20110116113217 / \mathrm{http} / /$ www.food.gov.uk/news $/$ newsarchive $/ 2003 / \mathrm{may} /$ waterchickenupdate? $\mathrm{view}=$ printerfriendly. Accessed 27 June 2016.

Food Standards Agency UK (FSA). 2009. Illegal meat: Guidance for Local Enforcement Authorities in Wales. http:/www.food.gov.uk/sites/default/files/multimedia/pdfs/illegalmeatguidw09.pdf. Accessed 21 June 2016.

Food Standards Agency UK (FSA). 2013. Horse DNA detected in canned beef from Romania. http://webarchive. nationalarchives.gov.uk/20150624093026/http://food.gov.uk/news-updates/news/2013/5858/canned-beef. Accessed 7 June 2016.

Food Standards Agency UK (FSA). 2014. FSA publishes latest report on industry beef product test results. http://webarchive.nationalarchives.gov.uk/20150624093026/http://food.gov.uk/news-updates/news/2014 /5950/test-results. Accessed 7 June 2016.

Food Standards Agency UK (FSA). 2015. FSA welcomes horse meat sentencing. http://webarchive. nationalarchives.gov.uk/20150624093026/http:/www.food.gov.uk/news-updates/news/2015/13747/fsawelcomes-horsemeat-sentencing. Accessed 7 June 2016.

Food Standards Agency (England) (FSA) \& Food Standards Scotland (FSS). 2016. Food crime: Annual strategic assessment- A 2016 baseline. https:/www.food.gov.uk/sites/default/files/fsa-food-crime-assessment-2016. pdf. Accessed 26 June 2016. 
Fuseini, A., T.G. Knowles, P.J. Hadley, and S.B. Wotton. 2016a. Halal stunning and slaughter: Criteria for the assessment of dead animals. Meat Science 119: 132-137.

Fuseini, A., T.G. Knowles, J.A. Lines, P.J. Hadley, and S.B. Wotton. 2016b. The stunning and slaughter of cattle within the EU: A review of the current situation with regard to the halal market. Animal Welfare (in-print).

Federation of Veterinarians of Europe (FVE). 2016. Slaughter of animals without prior stunning: FVE position paper. http://www.fve.org/news/position_papers/animal_welfare/fve_02_104_slaughter_prior_stunning.pdf. Accessed 13 June 2016.

Glitsch, K. 2000. Consumer perception of fresh meat quality: Cross-national comparison. British Food Journal 102: $177-194$.

Global Meat News. 2016. Fera Science enters into partnership with Malaysia on Halal proficiency. http://www. globalmeatnews.com/Financial/Fera-Science-enters-into-partnership-with-Malaysia-on-halal-proficiency. Accessed 27 June 2016.

Gomes Neves, J.E., M.J.R. Paranhos da Costa, R. Roca, N.G. Gregory, and L. Faucitano. 2009. Comparison of slaughter methods with or without previous stunning on animal welfare and bleeding efficiency in bulls. Journal of Animal Science 87(E-Suppl. 2): 6.

Halal Food Authority (HFA). 2016. Origin of Halal Food Authority. http://halalfoodauthority.com/origin-ofhalal-food-authority/. Accessed 14 June 2016.

Huffington Post. 2014a. Cadbury Malaysia upsets Muslims after pork DNA found in 'Halal chocolate. http://www.huffingtonpost.com/2014/05/28/cadbury-malaysia-muslims-pork-halal_n_5404555.html. Accessed 7 June 2016.

Huffington Post. 2014b. Halal meat may be processed differently, but is it safe? http://www.huffingtonpost. ca/steven-burton/halal-meat-processing_b_5716361.html. Accessed 21 June 2016.

International Business Times. 2015. Halal Pork? Aldi Supermarket Apologizes To Muslims After Selling 'HalalCertified' Black Pudding With Pig Blood. http://www.ibtimes.com/halal-pork-aldi-supermarket-apologizesmuslims-after-selling-halal-certified-black-1927312. Accessed 28 June 2016.

ITV News. 2013. Pork found in Halal meat in Birmingham. http://www.itv.com/news/central/update/2013-03-27 /pork-found-in-halal-meat-in-birmingham/. Accessed 6 June 2016.

Khalid, R., T.G. Knowles, and S.B. Wotton. 2015. A comparison of blood loss during Halal slaughter of lambs following traditional religious slaughter without stunning, electric head-only stunning and post-cut electric head-only stunning. Meat Science 110: 15-23.

Kirton, A.H., L.F. Frazerhurst, E.G. Woods, and B.B. Chrystall. 1981. The effect of electrical stunning method and cardiac arrest on bleeding efficiency, residual blood and blood splash in lambs. Meat Science 5: 347353.

Lever, J., and M. Miele. 2012. The growth of the halal meat markets in Europe: An exploration of the supply side theory of religion. Journal of Rural Studies 28: 528-553.

Mail Online. 2015. Muslims fury after Aldi is found selling 'halal' Indian-style snacks that contained forbidden PORK. http://www.dailymail.co.uk/news/article-3083780/Aldi-apologises-offering-halal-haggis-blackpudding-Muslims-forbidden-eating-unclean-meat.html. Accessed 7 June 2016.

Manning, L., and J.M. Soon. 2014. Developing systems to control food adulteration. Food Policy 49: 23-32.

Manning, L., R. Smith, and J.M. Soon. 2016. Developing an organizational typography of criminals in the meat supply chain. Food Policy 59: 44-54.

Murugaiah, C., Z.M. Noor, M. Mastakim, L.M. Bilung, J. Selamat, and S. Radu. 2009. Meat species identification and Halal authentication analysis using mitochondria DNA. Meat Science 83: 57-61.

Newsweek. 2015. Animal cruelty at Halal slaughterhouse highlights widespread abuse in the UK. http://europe. newsweek.com/animal-cruelty-halal-slaughterhouse-highlights-widespread-abuse-uk-304152. Accessed 29 June 2016.

Orford, F., E.A. Ford, S.N. Brown, J.L. McKinstry, P.J. Hadley, J. Lines, T.G. Knowles, and S. Wotton. 2016. The evaluation of two commercial electric sheep stunning systems: Current applied and the effect on heart function. Animal Welfare (In-press).

Organisation of Islamic Cooperation (OIC). 2015. Forum on unifying halal standards and procedures kicks off at OIC General Secretariat, Jedda. http://www.oic-oci.org/oicv2/m/en/topic/?t_id=10714\&t_ref=4218\&lan=en. Accessed 14 June 2016.

PETA. 2009. The cruelty behind Muslim ritual slaughter. http://www.peta.org/blog/cruelty-behind-muslim-ritualslaughter/. Accessed 29 June 2016.

Pew Research Centre. 2015. The Future of the world religions: Population growth projections, 20102050. http://www.pewforum.org/2015/04/02/religious-projections-2010-2050/. Accessed 7 June 2016.

Pointing, J., and Y. Teinaz. 2004. Halal meat and food Food Crime in the UK. International Halal Food Seminar. Malaysia: Islamic University College of Malaysia. 
Pointing, J., Y. Teinaz, and S. Shafi. 2008. Illegal labelling and sales of Halal meat and food products. The Journal of Criminal Law 72: 206-213.

Riaz, M.N. 1996. Hailing halal. Prepared Foods 165: 53-54.

Royal Society for the Protection and Cruelty to Animals (RSPCA). 2015. Slaughter without pre-stunning (for religious purposes): RSPCA Farm Animal Department Information Sheet. https://webcache. googleusercontent.com/search? q=cache:w 3 tCG3 y $822 \mathrm{gJ}:$ https://www.rspca.org. uk/ImageLocator/LocateAsset\%3Fasset\%3Ddocument\%26assetId\%3D1232719611043\%26mode\%3 Dprd+\&cd=1\&hl=en\&ct=clnk\&gl=uk\&client=safari. Accessed 13 June 2016.

Sirajuddin, M.D., M. Sahri, M.M. Khalid, M.A.Z. Yaakob, and H.M.F. Harun. 2013. Introducing Halalan Tayyiban concept in global industry practices: An innovative attempt. International Proceedings of Economics Development and Research 66: 44-49.

Stamoulis, P., C. Stamatis, T. Sarafidou, and Z. Mamuris. 2010. Development and application of molecular markers for poultry meat identification in food chain. Food Control 21: 1061-1065.

Sungkar, I. 2008. The global Halal trade, trends and issues. The Halal Journal 32-34.

Talib, M.S.A., and Johan, M.R.M. 2012. Issues in Halal packaging: a conceptual paper. International Business and Management 2:94-98.

Tahkapaa, S., R. Maijala, H. Korkeala, and M. Nevas. 2015. Patterns of food frauds and adulterations reported in the EU rapid alert system for food and feed in Finland. Food Control 47: 175-184.

Temporal, P. 2011. Islamic branding and marketing: Creating a global Islamic business. United States: Wiley.

The Evening Times. 2016. A tonne of meat seized by food safety officers from halal butchers in Glasgow. http://www.eveningtimes.co.uk/news/14227373.A_tonne_of_meat_seized_by_food_safety_officers_from_ halal_butchers_in_Glasgow/. Accessed 18 Jan 2017.

The Guardian. 2013a. Horsemeat scandal: Timeline. https://www.theguardian.com/uk/2013/may/10/horsemeatscandal-timeline-investigation. Accessed 7 June 2016.

The Guardian. 2013b. 'Halal pork' supplier named. http://www.theguardian.com/world/2013/feb/03/supplierhalal-meat-pork-dna-named. Accessed 7 June 2016.

The Halal Times. 2014. Fake Birmingham Halal meat company fined £62,000. http://www.halaltimes.com/fakebirmingham-halal-meat-company-fined-62000-pounds/. Accessed 28 June 2016.

The Telegraph. 2014. Find out which supermarkets and restaurants sell Halal meat: which restaurants, fast food chains and supermarkets near you sell halal meat, and how is it labelled? http://www.telegraph.co. uk/foodanddrink/10816716/Find-out-which-supermarkets-and-restaurants-sell-halal-meat.html. Accessed 13 June 2016.

Ulca, P., H. Balta, I. Cagin, and H.Z. Senyuva. 2013. Meat species identification and Halal authentication using PCR analysis of raw and cooked traditional Turkish foods. Meat Science 94: 280-284.

Wotton, S.B., X. Zhang, J. Mckinstry, A. Velarde, and T.G. Knowles. 2014. The effect of the required current/ frequency combinations (EC 1099/2009) on the incidence of cardiac arrest in broilers stunned and slaughtered for the Halal market. Peer J Pre Prints 2: e255v1. doi:10.7287/peerj.preprints.255v1. Accessed 05 May 2016. 